\title{
LAW OF SPORT AND ATHLETE FOOTBALL PROFESSIONAL
}

\author{
Antonius Feninlambir \\ Tomy Michael \\ Faculty of Law, University of 17 Agustus 1945 Surabaya \\ e-mail: a_los_tesalonicenses@yahoo.com
}

\begin{abstract}
ABSTRAK
Kemakmuran atlet sepak bola professional atau karyawan, adalah hak setiap karyawan. Merupakan tanggung jawab organisasi profesional sepak bola untuk bekerja dengan menjamin kesehatan dan keselamatan. Organisasi profesional sepak bola memiliki tanggung jawab penuh dalam hal ini. Melalui penelitian hukum normatif, hasil yang diperoleh disana adalah tidak ada korelasi antara hukum positif di Negara Kesatuan Republik Indonesia dan undang-undang yang dibuat oleh FIFA. Organisasi klub sepak bola profesional tidak benar-benar dijalankan dalam Undang-Undang Nomor 13 tahun 2003, Pasal 87 pada tenaga kerja dimana setiap perusahaan harus menerapkan kesehatan dan keselamatan sistem manajemen terintegrasi dan sistem manajemen kesehatan. Oleh karena itu diperlukan aturan hukum yang selaras dengan peraturan yang dibuat oleh FIFA, PSSI dihormati untuk peraturan di Indonesia yang berhubungan dengan olahraga yang melakukan tidak ada kontradiksi sebelum diterbitkan undang-undang organisasi, sehingga acara pengunduran diri atlet profesional sepak bola di masa depan, harus memperhitungkan isi dari kontrak mereka
\end{abstract}

Kata Kunci: sepakbola, FIFA, PSSI, atlet.

\begin{abstract}
Prosperity of athlete football professional or employees is the right of every employees. The responsibility of the organization of professional football clubs to occupational with their health and safety. Organization of professional football clubs have full responsibility in this regard. With normative legal research. The result obtained there is no correlation between positive of law in Unity State Republic of Indonesia and the statuten made by FIFA. Organization of professional football clubs have not been absolutly run in Law of Republic of Indonesia No. 13 of 2003, Article 87 on labour in which every company must implement a health and safety of management system integrated working with the health management system. As a suggestion, require the rule of law which is in sync with the regulations made by FIFA, PSSI respected to the regulations in Indonesia related to sports that do not event of contradiction before publish the statuten of the organization so that no event of resignation athlete professional football in the future, they shall take into account the contennt of their contract, the public take an active role in infraction notice made by PSSI or other organizations professional football clubs on the regulation of professional football athlete contract that have been made, and the researchers of science of law are examining the country's sovereignty and the sovereignty of FIFA.
\end{abstract}

Keywords: upholder in law, sportsman, football, system.

\section{INTRODUCTION}

In the Law of Republic of Indonesia No. 13 of 2003, Article 1 (15) concerning Manpower (State Gazette of Republic of Indonesia No. 39 of 2003, Addition of State Gazette of the Republic of Indonesia No. 4279) the employment relationship is the relationship between the employer and the workers or laborers based on labor agreements that have subtance of work, wages, and commands. Thus the employment relationship occurs because of the labor agreements between employment and wokers or laborers. The relationship as a form of legal relationship in born or created after an agreements 
between workers and employer. Doing of substance employment agreement must not conflict with the labor agreement or cooperation agreement or collective agreements existing cooperation agreement, thus its in company regulations, the substance must not in contradiction with the cooperation agreement or cooperative agreement. On this basic, the discussion of relationship on the third working will be addressed in an integrated manner because it is a unity that can not be separated as a component of industrial relations. The Law of Republic of Indonesia No. 13 of 2003, Article 1 verse 14 concerning Manpower (State Gazette of Republic of Indonesia No. 39 of 2003, Addition of State Gazette of the Republic of Indonesia No. 4279), an agreeement is an agreement between the worker or laborers and employers which contains the terms of right of employment and obligations of both parties.

With the development of football very repidly in Indonesia, it would require a container that holds all activities in football so that football can be played in an orderly and professional. Indonesia as a member of Federation Internationale De Football Association (FIFA) to form an umbrella organization engaged in football and called the Indonesian Football Federation or Football Association of Indonesia. It is established in Yogyakarta on April 19, 1930, the legal status registered in the Department of Justice through the Decree of the Minister of Justice No. J.A.5/11/b on February 2, 1953, the Official Gazette of Rupublic of Indonesia No. 18 on March 3, 1953. ${ }^{1}$

Nowadays athlete professional football can be classified as a workers or laborer in the football industry so that the Law of Republic of Indonesia No. 13 of 2003 concerning Manpower (State Gazette of Republic of Indonesia No. 39 of 2003, Addition of State Gazette of the Republic of Indonesia No. 4279) can be applied in the world of football for athlete professional football or the organization of professional football clubs itself in order to become a guide so there is no dispute between athlete professional football and the organization of professional football clubs and it is regulated under the law. The relations in the football industry started after managers as part of the organization of professional football clubs make a contract with athlete football contains the rights and obligations of the parties as

${ }^{1}$ Basic Guidelines Football Association of Indonesia of 2009, article 3 point 3.3. well as the terms of employment, including wages, duration of time employment contracts, insurance for them and the guarantee of health and safety at work.

The relations occur after the employment agreement, an agreement where workers expressed willingness to work on the company or the employer for a wage and companies or employers expressed willingness to hire workers to pay wages. Athlete professional football are playing in the highest league Indonesia.

\section{DISCUSSION}

\section{Professional Football Player Contract Minimum Requirements}

Protecting the interests of athlete professional football, FIFA has made reference contained in the Circular Letter No.1171 November 24, 2008 Regarding Professional Football Player Contract Minimum Requirements (CL No. 1171). The CL No.1171 arranged in clearly indicating the clauses which must be regulated in a contract between athlete professional football and the organization of profesional football clubs, some of the points as:

First, Supervision of Fill of Professional Contracts. One of protection to athlete professional football is with the directly system by an institution that is recognized football association in this case Football Association of Indonesia. The provisions of points 1.2 CL No.1171 set as: Each signatory party must receive a copy of the contract and one copy must be forwarded to the Professional League and/or Member of Association for registration according to the provision of the competent football body.

The essence of the law is duty from Football Association of Indonesia is overseeing of the contracts which is not only aims to protect the athlete football but also controling on the clauses within the contracts, it is appropriate with the statuta and the regulations of FIFA and the Football Association of Indonesia as well as the provisions of employment in Indonesia.

Second, The Organization of Professional Clubs as the Party in the Contract of Athele Professional Football. In connection with the status of the organization football clubs, the provisions of points 1.4 CL No.1171 clearly stated as: The agreement states the full legal name of the club (incl register number) and its full address as well as the name, sure name, and address of the person who is legally representing the club. A professional football player 
contract can only be concluded by a football club and its legal entity. Such entity is defined by National Club Licensing Manual or Regulations as license applicant. It must be a direct or indirect member of national football association and or professional league and be dully registered. Any other legal entity may not conclude such a player contract without the prior consent of the competent national football body and or FIFA.

In civil or the law of employment of course the professional contracts remained valid and binding on the parties, but the contract can not be protected by the rules of FIFA because the organization is not recognized by FIFA itself.

Third, Legal Compliance. Sometimes Football Worls Cup under FIFA caused in the countries of FIFA within the country is a member of, which in many aspects to sync of regulations is necessary so that the regulations of FIFA are enforceable in the countries that are members. However, particulars of law of employment, the FIFA stipulated in Points 3.1 CL No.1171 which clearly recognized the law of employment in force, as it reads as: The agreement regulates an employment contract for professional player. The national legislation of the country where the club is dully registered applies, if another legislation is not otherwise agreed. National labour law may provide mandatory provisions, which cannot be amended by the parties and have to be taken into account.

However, on other hand of Points 11.2 CL No.1171 arranged: The club and player must comply with the statutes, regulations including the code of ethics, the decisions of FIFA, Confederations, the member association as well as the Professional League (if applicable) which form an integral part of this agreement, the parties acknowledge this through their signature.

Based on two regulations above, then the contract shall obey two different rules that is the positive law of employment in Indonesia and the statuta of FIFA and the Football Association of Indonesia because it is as a member of FIFA.

\section{The Law of Sports}

A Rigozzi, provide an understanding of the Lex Sportiva as a series of private legal norms derived from the interaction between the norms of the law's sports and the general principles in accordance with the legal systems of the state, as embodied in the arbitration-sports arbitrage. ${ }^{2}$

The law's sports is a translation of lex sportiva, ${ }^{3}$ which is growing rapidly now, especially it is starting from Greece and Europe since 1984. Simply, lex sportiva can be formulated as a law that specifically regulates the sports established by the institution itself and the sports community applies and enforced by the sports institute itself without the intervention of the positive law of the country and international law. Dimtiros Panagiotopoulos stated that: Lex Sportiva is a legal order, which incorporates stateadopted law and the law adopted by the national and international bodies representing organized sport. These bodies operate to the standards of unions and in the context of the autonomy granted to such bodies and operate within states in a pyramid, like fashion and at international level in the form of a special relationship linking them to the relevant international sports federation. The law produced in this manner is thus a law which is, in essence, non-national law, which claims for itself direct and preferential application within sports legal orders and the par excellence law in sports life".

The law's sports in the international level is sui generis legal order. Dimitrios Panagiotopoulos said that Lex Sportiva, as a system for applying sports law rules at international sporting level, is a sui generis legal order, which has its own jurisdictional body, the CAS, based in Lausanne, to protect and ensure the application of its provisions. Thus issues on the sanctions imposed and the implementation and execution of the decisions of this court of arbitration, and the issue of its problem-free integration in national jurisdictional system are of capital importance for this manner.

2 A Rigozzi, quote by Franck Latty, Nieuwenhuis, Hoofdstukken Verbintenissenrechtn, 945, p. 91-92.

${ }^{3}$ Lex (leks), n. [Latin "law"] 1. Law, esp. statutory law. 2. Positive law, as opposed to natural law. Strictly speaking, lex is a statute, whereas jus is law in general (as well as a right). 3. A system or body oflaws, written or unwritten, that are peculiar to a jurisdiction or to a field of human activity. 4. A collection of uncodified laws within a jurisdiction. 5. LEX PUBLICA. 6. LEX PRIVATA. 7. Civil law. A legislative bill.PI.leges (leejeez). $C t$ : JUS. 8. The acquisition of property under some specific law, when the property is made over by a magistrate to the claimant. 9. A term of a contract, treaty, or other agreement. Bryan A Garner, Black's Law Dictionary, Ninth Edition, (United States of America: Thomson Reuters, 2009), p. 991. 
Besides of Lex Sportiva, there are called Lex Lucida is referred to as the sporting law is the Rules of the Game. Ken Foster explained as: These encompass two types of rules that are distinctive and unique because of the context of sport in which they occur and are applied. One covers the actual rules of the game and their enforcement by match officials. The approach here by the Court of Arbitration for Sport has been to treat these rules as sacrosanct and immune from legal intervention. The second type is what can be termed the sporting spirit and covers those ethical principles of sport that should be followed by sporst persons. The concept lex ludica thus includes both the formal rules and the equitable an internal law of sport a private governance that is respected by national courts, and as such is best applied by a specialized forum or system arbitration by experts.

Neither of the Lex Sportiva and against Lex Ludica, the state can not intervene, either using the mechanisms of international law and the national legal mechanisms. The law's sports (which includes Lex Ludica) are become part of the regime's Global Sports Law now, which is defined as an order of independen of law and transnational created by global private institutions to organize, manage and organize a football internationally that is global, sovereign and have immunity of authority to manage, organize and resolve disputes professionla football of the positive law of a country and international law.

Thus, it is not exaggeration to say that the actual law of the national sport of Innonesia focused on the Law of Republic of Indonesia No. 3 of 2005 on National Sports System (State Gazette of the Republic of Indonesia No. 89 of 2005, Supplement to the State Gazette of the Republic of Indonesia No. 4535 of 2005) and the third Regulations of the Government are the Republic of Indonesia Government Regulation No. 17 of 2007 on the Implementation of Fair and Championship Sports (State Gazette of the Republic of Indonesia No. 36 of 2007, Supplement to the State Gazette of the Republic of Indonesia No. 4703), the Republic of Indonesia Government Regulation No. 16 of 2007 (State Gazette of the Republic of Indonesia No. 35 of 2007, Supplement to the State Gazette of the Republic of Indonesia No. 4702), the Republic of Indonesia Government Regulation No. 18 of 2007 concerning the Funding of Sports (State Gazette of the Republic of Indonesia No. 37 of 2007, Supplement to the State Gazette of the Republic of Indonesia No. 4704).

Comparison of Lex Sportiva and Lex Ludica

\begin{tabular}{cll}
\hline No & \multicolumn{1}{c}{ Lex Sportiva } & \multicolumn{1}{c}{ Lex Ludica } \\
1. & $\begin{array}{l}\text { Regulations and norms } \\
\text { make by each International } \\
\text { Federation Sports. }\end{array}$ & $\begin{array}{l}\text { The regulations } \\
\text { organize of the } \\
\text { football competitions. } \\
\text { The regulations are } \\
\text { technical. (rules of } \\
\text { the game). }\end{array}$ \\
$\begin{array}{l}\text { Regulations for sports are } \\
\text { influencing the rumors of } \\
\text { sport life. }\end{array}$ & $\begin{array}{l}\text { The rules of autonomy of } \\
\text { league private sports. } \\
\text { The laws organize the } \\
\text { common problem about sport } \\
\text { and }\end{array}$ \\
\hline
\end{tabular}

\section{Standard Health and Safety in Football}

Football was a sport that forces the body to work to reach capacity limits the ability of the body. In one match, not infrequently, both of teams are equally determined to pursue the victory, so that the impact in light in weight, or severe collision that leads to danger. Some of security tools that take to the player certainly does not guarantee. The tools are only slightly protect certain part of body most prone to danger.

To avoid things that are not desirable, FIFA make medical standards should be provided at every football game. The first is the medical standards for medic, both prepared by each organization of professional football clubs and those provided by the organizing committee of the match.

Each clubs shall have a minimum of a doctor and a physiotherapist with the standards set by FIFA. Doctors must have a certificate of training in medical treatment for football of the FIFA or the assiciation in the country. It is important to remember that medical personnel are the only person who has the right to make medical treatment of players or officials were injured or suffered from health problems. In addition to doctors, during the game, there should not be any party who perform medical procedures.

Every medical personnel who are part of the club was required to be present in the field in every game because it is only those who have the right to medical treatment. The match organizer or usually cage team must also provide one another doctor as doctor in the game. He will act in the event something unexpected should be urgent. 
In addition to a doctor, the match organizers must provide other medical personnel are always ready to carry a stretcher and equipment of P3K. They must be available to provide assistance to the doctors when the players are injured. As doctors, medical workers should be qualified in accordance with FIFA standards. In terms of equipment, FIFA has been very clearly instructed medical devives which must be prepared by the medical team in game as well as the team doctors. FIFA calls it in a bag called the Federation Internationale De Football Association Medical Emergency Bag. Some of the equipment should be available in this bag is the infusion apparatus, ventilation bag, blood pressure monitor, and several other medicals.

In the stadium, an ambulance has been the vehicle that must be always ready to take them to the nearest hospital that has been referrend to the match. Stadiums also have to provide a separate room to do all the handling medis. Concerning of some rules that must be met by medical room, includes : sterile, the forbidden zone for anyone other than a medical team, should be used for medical activities, accessible from the field and the locker room, and some other regulations.

Another prevention of FIFA is make the rules to avoid something unwanted. Basically, the law's sports was made to make final of game be fair for both teams. Yet another aim is no less important is to prevent excessive action that could endanger for other players as well as himself.

FIFA set a few actions considered that misdemeanors, violations must be given a warming, until the gross of violations which then cause a player send off. Players should be given more of a suspended sentence in a specific amount. Existing regulations always evaluated to upgrading. The aim is for health and safety of athlete football professional. An example is when the football marred by numerous incidents of broken leg in a few years ago. Then, FIFA tightened the rules about sliding tackle. No more tolerance for players who perform these actions using both legs.

The first legas cases. Diego Mendieta is a athlete football professional from Paraguay who played in Indonesia club of the Football Association of Indonesia Entire Solo. Diego Mendieta, died on December 4, 2012 when the Football Association of Indonesia Entire Solo has not been paid his salary, who competed in the top division in PT League
Indonesia. Diego was pass away in Solo because of cytomegalovirus which is attacked the brain. Besides of viruses, there was mold growing in the esophagus and gastrointestinal tract. These was made him no taste to eat and body resistance is declining while still undergoing treatment at dr. Moewardi Hospital. At the moment in his treatment, Diego was forced to move around the hospital because he do not have a cost. The Football Association of Indonesia Entire Solo still have debts, let him have trouble while in the hospital. The reason, the club has no money. All the players had not yet received their salary. However, the management argued if Diego had not of their player since the end of the primary division competition. So, they had not obligation to help his treatment. How the solve of the organization football clubs professional. After Diego died, the Football Association of Indonesia Entire Solo eventually paid off all his debts. In fact they paid Diego's salary of four months. Diego's salary transferred to his wife's account, Valeria Alvarez Ibanez. All of Diego's salary was paid and transferred to his wife's account. All the players agreed that their salary was rationalized. "However, there are exceptions to Diego because of humanitarian considerations, “ Totok Supriyanto said, a former manager of the Football Association of Indonesia Entire Solo. ${ }^{4}$

From the incident, the author analyze the legal issues is that the guilty party and entitled to obligate the risk is the organization of football clubs whom the Football Association of Indonesia Entire Solo, because they are violating the Law of Republic of Indonesia, such as:

First, The Law of Republic of Indonesia No. 3 of 1992 on Social Security Workers, The State Gazette of Republic of Indonesia No. 14 of 1992, Supplement State Gazette No. 3468: The Organization of football clubs professional break of Article 1 point 1 assurance of social security is a protection for workers is compensation in the form of money as a partial replacement of lost income or reduced and the waiter as a result of the incident or something happen with them as like accidents, illness, pregnancy, maternity, old age, and death. The Article 3 point (1) provides the protection to workers which organized by labor social security programs that processing can be carried out

${ }^{4}$ http://www.goal.com/id-ID/news/1387/nasional/2012/ 12/06/3582390/kasus-diego-mendieta-perburuk-sepak bolaindonesia, access on 1 July 2015. 
with an insurance mechanism, point (1) All of the workers are entitled to social security. The Article 4 point (1) social security programs is as referred to in the Article 3 is done by every company for workers which accordance with the provisions of the law. The Article 12 point (1) workers who died is not because of accidents, the family is entitled to death benefits, point (1) death benefits referred to in point (1) such as: widow or widower, children, parents, grandchildren, grandfather or grandmother, siblings, and mother or father in law.

Second, The Law of Republic of Indonesia No. 13 of 2003 concerning Manpower (the State Gazette of Republic of Indonesia No. 39 of 2003, Supplement State Gazette No. 4279): The organization of football clubs violates the Article 1 point 6 of the company is: any form of business which legal entity or not, owned by an individual, partnership or a legal entity, either owned or state-owned provate individual who employs workers or laborers by paying them wages or other forms of remuneration; and social enterprises and other bussiness with officials and hire someone else to pay wages or other forms of remuneration. The Article 44 foreign workers employers must comply with the provisions concerning with occupations and competence standards in force. The Article 47 the employer is obliged to pay compensation for each foreign worker it employs. The Article 87 every company must implement a safety management system and integrity of occupational health with management system of company. The Article 99 point (1) of each workers or laborers and their families are entitled to receive the social security. The Article 126 point (3) employers must print and distribute the proposal agreement to each workers or laborers at the expense pf the company.

Third, The Law of Republic of Indonesia No. 3 of 2005 on National Sports System (the State Gazette of Republic of Indonesia No. 89 of 2005, Supplement State Gazette No. 4535): The Organization of football clubs violates the Article 1 point 15 professional sports is a sport that is performed to generate income in the form of money or other forms based on finesse of athlete. The Article 51 point (1) the organization of sport must fulfill the technical requirements of branch, health, salvation, and provisions of the local area. Settlement: the Article 88 point (1) the settlement of disputation in the sports pursued through deliberation and consesus carried out by the parent in organization of the sport.

The second legas cases. Abdulaye Sekou Camara is athlete football professional from Mali who played in organization of Pelita Bandung Raya Football Club, died on July 27, 2013. News of his death is certainly surprising every parties. For a few hours earlier, he did not indicate the condition of illness or other problems. While he training with the squad Pelita Bandung Raya in the stadium Siliwangi in Bandung, West Java, Sekou suddenly fell and died in the moment later. According to the doctors, Sekou had a heart attack. When he tied his shoelace he had fallen. Because look at it, we are immediately brought him to the nearest hospital, Marco Gracia Paolo as Chief Executive Officer PT Kreasi Performa Pasundan (manager Pelita Bandung Raya) said. Settlement taken by the club is a bear all costs to repatriate his body to his country of Mali and provided compensation money for his family. ${ }^{5}$

From the incident, the authors had concluded that the guilty party and had responsibility of the risk of these events is the organization of Indonesia Football Club in this case Pelita Bandung Raya Football Club where he was an athlete and worker, because violating the legislation in the Republic of Indonesia, such as:

First, The Law of Republic of Indonesia No. 3 of 1992 on Social Workers (the State Gazette of Republic of Indonesia No. 14 of 1992, Supplement State Gazette No. 3468: The organization of football clubs professional are break of the Article 1 point 1 of Social Security is a protection for workers in the form of compensation in the form of money as a partial replacement of lost income or reduced and service as a result of incident or something happen occur by workers like accidents, illness, pregnancy, maternity, old age, and death. The Article 3 point (1) provide the protection for workers which organized by labor of social security programs that processing can be carried out with an insurance, point (2) all workers are entitled to social security. The Article 4 point (1) social security programs are referred to the Article 3 is done by every company for their workers which accordance with the provisions of the law. The Article 12 point (1) workers who died is not because of accidents, the family is entitled to death benefits, point (1) death benefits referred

\footnotetext{
5 http://bola.liputan6.com/read/651143/catatan-singkatkarier-sekou-camara, access on 1 July 2015.
} 
to in point (1) such as: a. widow or widower, b. children, c. parents, d. grandchildren, e. grandfather or grandmother, f. siblings, g. mother or father in law. Criminal sanctions: Article 29 point (1) Whoever does not fulfill the obligations referred to in Article 4 poin (1); Article 10 point (1), point (2), and point (3); Article 18 point (1), point (3), point (4), and point (5); Article 19 point (2); Article 22 point (1); and Article 26, it shall be punishable with imprisonment for ever six (6) months or a maximum fine of Rp. 50.000.000,- (fifty million rupiahs).

Second, The Law of Republic of Indonesia No. 13 of 2003 concerning Manpower (the State Gazette of Republic of Indonesia No. 39 of 2003, Supplement State Gazette No. 4279): The organization of football clubs violates the Article 1 point 6 of the company is: a. any form of business which legal entity or not, owned by an individual, a. partnership or a legal entity, either owned or state-owned provate individual who employs workers or laborers by paying them wages or other forms of remuneration; $b$. social enterprises and other bussiness with officials and hire someone else to pay wages or other forms of remuneration. The Article 44 foreign workers employers must comply with the provisions concerning with occupations and competence standards in force. The Article 47 the employer is obliged to pay compensation for each foreign worker it employs. The Article 87 every company must implement a safety management system and integrity of occupational health with management system of company. The Article 99 point (1) of each workers or laborers and their families are entitled to receive the social security. The Article 126 point (3) employers must print and distribute the proposal agreement to each workers or laborers at the expense pf the company.

Third, The Law of Republic of Indonesia No. 3 of 2005 on National Sports System (the State Gazette of Republic of Indonesia No. 89 of 2005, Supplement State Gazette No. 4535): The Organization of football clubs violates the Article 1 point 15 professional sports is a sport that is performed to generate income in the form of money or other forms based on finesse of athlete. The Article 51 point (1) the organization of sport must fulfill the technical requirements of branch, health, salvation, amd provisions of the local area. Criminal sanctions : the Article 89 point (1) any person conducting sporting events does not fulfill referred to with the Article 51 point (1) and point (2) shall be punished with imprisonment of two (2) years and/ or a maximum fine of Rp. 1.000.000.000.00 (one billion rupiah). Settlement: the Article 88 point (1) the settlement of disputation in the sports pursued through deliberation and consesus carried out by the parent in organization of the sport.

The third legal cases. Bruno Zandonadi is a athlete football professional from Brasil who played in the organization football clubs professional that is the Football Association of Indonesia Entire Tangerang, died on October 13, 2012, he was in a coma for four days, before dying in the Intensive Care room in the Unit of Usada Insani Hospital, Tangerang, cause of his death due to meningitis. Bruno's friend, Christian Carrasco, said that Bruno had long complained of paid in his head. But, Bruno is not too observe his illness and not taken to the doctor. On Monday, he was admitted to hospital for treatment and newly discovered the disease. The doctor said he was suffering from meningitis, Carrasco said. On Thursday, Bruno's condition declining and breathing aided by a ventilator. His condition did not improve, until finally died on Saturday morning. Settlement conducted by the Football Association of Tangerang Club gave donations to his wife, Annie Sanjaya, and his daughter, Isabel Nezwa Zandonadi. Also bear all of the burial costs of Bruno was buried in Sepanjang, Cisoka, Tangerang. ${ }^{6}$

From this case, the authors draw the conclusion that the guilty party and who is responsible for the risk of this case is the Football Association of Tangerang Club, because violating the legislation in the Republic of Indonesia, such as:

First, The Law of Republic of Indonesia No. 3 of 1992 on Social Workers (the State Gazette of Republic of Indonesia No. 14 of 1992, Supplement State Gazette No. 3468): The organization of football clubs professional are break of the Article 1 point 1 of Social Security is a protection for workers in the form of compensation in the form of money as a partial replacement of lost income or reduced and service as a result of incident or something happen occur by workers like accidents, illness, pregnancy, maternity, old age, and death. The Article 3 point (1) provide the protection for workers which organized by labor of social security programs that processing can be carried out with an insurance, point (2) all

6 http://bola.inilah.com/read/detail/1915576/inilahkronologi-kematian-bruno-zandonadi, access on 1 July 2015. 
workers are entitled to social security. The Article 4 point (1) social security programs are referred to the Article 3 is done by every company for their workers which accordance with the provisions of the law. The Article 12 point (1) workers who died is not because of accidents, the family is entitled to death benefits, point (1) death benefits referred to in point (1) such as: a. widow or widower, $b$. children, c. parents, d. grandchildren, e. grandfather or grandmother, f. siblings, g. mother or father in law. Criminal sanctions: Article 29 point (1) Whoever does not fulfill the obligations referred to in Article 4 poin (1); Article 10 point (1), point (2), and point (3); Article 18 point (1), point (3), point (4), and point (5); Article 19 point (2); Article 22 point (1); and Article 26, it shall be punishable with imprisonment for ever six (6) months or a maximum fine of Rp. 50.000 .000 ,- (fifty million rupiahs).

Second, The Law of Republic of Indonesia No. 13 of 2003 concerning Manpower, the State Gazette of Republic of Indonesia No. 39 of 2003, Supplement State Gazette No. 4279: The organization of football clubs violates the Article 1 point 6 of the company is: any form of business which legal entity or not, owned by an individual, partnership or a legal entity, either owned or state-owned provate individual who employs workers or laborers by paying them wages or other forms of remuneration; and social enterprises and other bussiness with officials and hire someone else to pay wages or other forms of remuneration. The Article 44 foreign workers employers must comply with the provisions concerning with occupations and competence standards in force. The Article 47 the employer is obliged to pay compensation for each foreign worker it employs. The Article 87 every company must implement a safety management system and integrity of occupational health with management system of company. The Article 99 point (1) of each workers or laborers and their families are entitled to receive the social security. The Article 126 point (3) employers must print and distribute the proposal agreement to each workers or laborers at the expense pf the company.

Third, The Law of Republic of Indonesia No. 3 of 2005 on National Sports System The State Gazette of Republic of Indonesia No. 89 of 2005, Supplement State Gazette No. 4535: The Organization of football clubs violates the Article 1 point 15 professional sports is a sport that is performed to generate income in the form of money or other forms based on finesse of athlete. The Article 51 point (1) the organization of sport must fulfill the technical requirements of branch, health, salvation, and provisions of the local area. Criminal sanctions : the Article 89 point (1) any person conducting sporting events does not fulfill referred to with the Article 51 point (1) and point (2) shall be punished with imprisonment of two (2) years and/ or a maximum fine of Rp. 1.000.000.000.00 (one billion rupiahs). Settlement: the Article 88 point (1) the settlement of disputation in the sports pursued through deliberation and consesus carried out by the parent in organization of the sport. National Dispute Resolution Chamber Point 10.2 CL No.1171 concerning the settlement of the conflict between the organization of football clubs and athlete football as: Subject to national legislation any dispute between club and the player regarding this employment contract shall be submitted to independent and impartial arbitration composed of equal representatives of each party (employer and employee) under the member of association statutes and regulations, or to CAS. Such decision are final, Under the conditions mentioned in the FIFA regulations on the status and transfer of players, disputes may be settled by the Disputes Resolution Chambers, with an appeal to CAS.

The mechanism of conflict resolution between the organization of football clubs profesional and athlete football professional shall be regulated in a contract of professional football, and that is obedient with positive law in Indonesia. The Article 29 the Law of Republic of Indonesia No. 2 of 2004 concerning Industrial Relations Dispute Settlement The State Gazette of the Republic of Indonesia No. 6 of 2004, Supplement State Gazette of the Republic of Indonesia No. 4356 stipulates explicitly: The settlement of industrial disputes through arbitration include disputes over interests and disputes inter-union or trade unions whithin one company. Futhermore in the Article 30 point (1) the Law of Republic of Indonesia No. 2 of 2004 concerning Industrial Relations Dispute Settlement (the State Gazette of the Republic of Indonesia No. 6 of 2004, Supplement State Gazette of the Republic of Indonesia No. 4356) stipulates: Arbitrators authorized to settle dispute of industrial relationship should arbitrators established by the Ministers.

The fourth legas cases. Athlete football professional from Brazilian, Neymar Santos Junior 
is play or work for football club that is Football Club Professional of Barcelona. He was injured on July 5, 2014, while he is defending the State of Brazil in the event of the 2014 World Cup held in Brazil, a team doctors of Brazil Rodrigo Lasmar reveals the fructure of the third lumbar vertebra. In other words fractured vertebrae or cracked his spine. That is occurred on the eve of the end of the match, Neymar winced in pain and had to be stretchered off due to receive the brunt from behind of athlete football professional from Colombian, Juan Camillo Zuniga. In reruns look back of Neymar hit the knee of Juan Camillo Zuniga during a duel in the air. ${ }^{7}$

At the time of Neymar injury was defending his country, the settlement is Brazil to bear all of the cost of the treatment and healing of him, but Football Club Barcelona feel have a contract with Neymar Junior, which is wrote in the Article 6 that the clubs have the dutry of Undertake an obligation to the welfare of the players as follows: the Welfare Facilities of Players, insurance, and the payment of income when the player can not perform if they have illness or injury, providing all the facilities and equipment they needed, the club providing insurance or another protection for them, so Foottball Club Barcelona also send the medical staff to Brazil to monitor and help the recovery of the injury and the conditions by Neymar.

The fifth legas cases. Christian Benitez was athlete football from Ecuador, 27-year-old who played in the football club El Jaish, Qatar. Earlier, Christian Benitez had rushed to a hospital nearby, after he complaining about abdominal pain. On July 30, 2013, the athlete called Cucho, he died because of a fatal heart attack. The news invite the attention of the football in world, because the illness to be the cause. The settlement of the club is bear all costs such as send the body of Christian Benitez to his country Ecuador and also provide funeral expenses as well as compensation in the form of money for the family of Christian Benitez. ${ }^{8}$

7 The researchers used two sources to complete the analysis, such as: 1 . http://m.bola.viva.co.id/news/read/519243-neymarcedera--brasil-kehilangan-separuh-nyawa, access on 4 July 2015; 2. http://brasil2014.kompas.com/read/2014/07/05/07122708/ tulang.belakang.retak.neymar.tak.bisa.tampil.lagi.di.piala.dunia, access on 4 July 2015.

${ }^{8} \mathrm{http}: / / \mathrm{m}$. bola.net/bola_dunia lainnya/simpati-fifa-atasmeninggalnya-cucho-benitez-096493.html, access on 4 July 2015.
The authors conclude that the case is in which the football club El Jaish felt responsible to Christian Benitez, which is written in the contract and then wrote in the Article 6 that the clubs have the dutry of; Undertake an obligation to the welfare of the players as follows: the Welfare Facilities of Players, insurance, and the payment of income when the player can not perform if they have illness or injury, providing all the facilities and equipment they needed, the club providing insurance or another protection for them. So the football club El Jaish shall replace all costs such as send the body of Christian Benitez, burial costs and the cost of compensation to the family.

\section{CONCLUSION AND SUGGESTION Conclusion}

Based on the research that has been described, the authors conclude:

First, There is no correlation between the positive law in the Republic of Indonesia and the statutes created or issued by FIFA, Association Asian Football Confederation. So that the positive law in Indonesia does not regulate in specifically on athlete football professional in Indonesia.

Second, The organization of football clubs in Indonesia has not fully run the Article 87 of the Law of Republic of Indonesia No. 13 of 2003 concerning Manpower (the State Gazette of Republic of Indonesia No. 39 of 2003, Supplement State Gazette No. 4279) that every company must implement a management system of health and safety that is integrated with the management system of health.

\section{Suggestions}

Based on the research that has been described, the authors ive suggestions such as:

First, For the government pf the Republic of Indonesia requires a rule of the positive law in Indonesia which is synchronous with the regulations issued by FIFA.

Second, For the organizations of Football Association of Indonesia should pay attention to the laws and regulations in Indonesia related to sports that do not conflict, before issuing the statutes of the organization so that no death event of athlete football in the future.

Third, For athlete football professional is obliged to pay attention to the content of the contract before 
it is signed and shall have an agent who knows the science of law so there is no dispute in the future.

Fourth, For the community to take an active role in observing the violations made by the organizations of Football Association of Indonesia as well as other football clubs on the regulations of athlete football's contract has been made. By reporting it to the authorities as a displinary commission belonging to Football Association of Indonesia or the Police of Republic of Indonesia.

Fifth, For the researchers jurisprudence is research the country's sovereignty and the rule of FIFA, the law which must be obeyed the organization of Football Association of Indonesia.

Sixth, For the universities, especially faculty of law is to introduce the law of sports as a part of the science of law.

\section{REFERENCES}

\section{Regulation:}

The Law of Republic of Indonesia No. 3 of 1992 on Social Security Workers (The State Gazette of Republic of Indonesia No. 14 of 1992, Supplement State Gazette No. 3468).

The Law of Republic of Indonesia No. 13 of 2003 concerning Manpower (State Gazette of Republic of Indonesia No. 39 of 2003, Addition of State Gazette of the Republic of Indonesia No. 4279).

The Law of Republic of Indonesia No. 3 of 2005 on National Sports System (State Gazette of the Republic of Indonesia No. 89 of 2005, Supplement to the State Gazette of the Republic of Indonesia No. 4535 of 2005).

The Republic of Indonesia Government Regulation No. 16 of 2007 (State Gazette of the Republic of Indonesia No. 35 of 2007, Supplement to the State Gazette of the Republic of Indonesia No. 4702).
The Republic of Indonesia Government Regulation No. 18 of 2007 concerning the Funding of Sports (State Gazette of the Republic of Indonesia No. 37 of 2007, Supplement to the State Gazette of the Republic of Indonesia No. 4704).

The third Regulations of the Government are the Republic of Indonesia Government Regulation No. 17 of 2007 on the Implementation of Fair and Championship Sports (State Gazette of the Republic of Indonesia No. 36 of 2007, Supplement to the State Gazette of the Republic of Indonesia No. 4703).

Department of Justice through the Decree of the Minister of Justice No. J.A.5/11/b on February 2, 1953, the Official Gazette of Rupublic of Indonesia No. 18 on March 3, 1953.

The Circular Letter No.1171 November 24, 2008 Regarding Professional Football Player Contract Minimum Requirements (CL No. 1171).

Basic Guidelines Football Association of Indonesia of 2009.

\section{Book:}

Bryan A. Garner, Black's Law Dictionary,Ninth Edition, United States of America: Thomson Reuters, 2009.

Nieuwenhuis, Hoofdstukken Verbintenissenrechtn, 1945.

\section{Website:}

http://bola.liputan6.com/read/651143/catatansingkat-karier-sekou-camara.

http://bola.inilah.com/read/detail/1915576/inilahkronologi-kematian-brunozandonadi.

h t t p : / / brasi 12014 . kompas .com/ $\mathrm{read} / 2014 / 07 / 05 / 07122708 /$ tulang.belakang. retak.neymar.tak.bisa.tampil.lagi.di.piala.dunia. http://m.bola.net/bola_dunia_lainnya/simpati-fifaatas-meninggalnya-cucho-benitez-096493.html. http://m.bola.viva.co.id/news/read/519243-neymarcedera--brasil-kehilangan-separuh-nyawa. 